\title{
Tubal and uterine secretions; the possibilities for contraceptive attack
}

\author{
R. J. Aitken \\ M.R.C. Unit of Reproductive Biology, 2 Forrest Road, Edinburgh EH1 2QW, U.K.
}

\section{Introduction}

In this article I shall be discussing our state of knowledge with respect to the composition and function of tubal and uterine secretions with particular reference to the possibilities for contraceptive attack. Before considering the secretions themselves it is important to establish the type of contraceptive we are hoping to develop as a result of these studies. One possible approach might be to search for specific proteins or glycoproteins in the genital tract secretions which are essential for the continuation of early embryonic development and which might, therefore, be used as targets for the immunological suppression of fertility. In both the tubal (Moghissi, 1970) and uterine (Roberts, Parker \& Henderson, 1976; Maathuis \& Aitken, 1978a, b) secretions of the human genital tract biochemical evidence exists for the presence of nonserum, possibly unique, proteins (Pl. 1, Fig. 1). The specificity of these proteins has not yet been established immunologically, however, and we may do well to remember that the protein "uteroglobin" (Krishnan \& Daniel, 1967; Beier, 1968) was thought to be a specific component of rabbit uterine secretions for a decade until it was also discovered in the lungs, tubal secretions and seminal plasma of this species (Noske \& Feigelson, 1976). Our uncertainty concerning the specificity of uterine and tubal proteins and the attendant hazards of autoimmune disease (Tung, 1976) should perhaps discourage us from this approach. An alternative route towards the immunological suppression of fertility might be to search for specific embryonic factors which are responsible for regulating the synthesis or release of critical components in the oviductal or uterine secretions. The advantage of this approach is that the target antigen is of embryonic origin and would, therefore, only be exposed to the maternal immune system for a limited period of time. The specificity of the embryonic factors involved would still have to be demonstrated however. Alternatively we might try to regulate the synthesis or release of critical secretory components by pharmacological means, using, for example, anti-oestrogens or antiprogestagens. Common to both the immunological and pharmacological approaches is the need to identify processes in early development in which tubal or uterine secretions play an important part. In the following sections I shall consider the possible roles played by these secretions and assemble the evidence for an embryonic or pharmacological influence on their composition.

\section{The oviduct}

Since the oviduct is the site of fertilization and subsequent cleavage of the embryo, oviductal secretions might play a role in such events as sperm capacitation, sperm binding, penetration of the zona pellucida, corona cell dispersal, the regulation of embryonic metabolism and the immunological protection of the zygote.

Capacitation of human spermatozoa can be readily achieved in vitro using a defined medium (such as M199) and a simple supplement of human serum albumin ( $3 \mathrm{mg} / \mathrm{ml}$ ). Human spermatozoa incubated in this medium for $5 \mathrm{~h}$ become fully capacitated and acquire the ability to penetrate the zona-free oocytes of mice or hamsters and form pronuclei (Pl. 1, Fig. 2: R. J. 
Aitken, D. Mortimer, D. W. Richardson \& A. Templeton, unpublished observations; Hanada \& Chang, 1972; Yanagimachi, 1972; Yanagimachi, Yanagimachi \& Rogers, 1976). Since serum albumin is present in the tubal (Moghissi, 1970) and uterine (Maathuis \& Aitken, 1978a, b) secretions of women at all stages of the cycle, there may be little prospect of interfering with capacitation for contraceptive purposes. Some evidence does exist, however, suggesting that sperm capacitation in vivo also involves the removal of a decapacitation factor acquired in the seminal plasma (Chang, 1957). Although this factor may be removed mechanically when spermatozoa are washed before fertilization in vitro the removal of the decapacitation factor in vivo may depend upon specific enzymes, possibly amylases, in the genital tract secretions. Another tubal factor which may be involved in the induction of sperm capacitation is calcium (Yanagimachi \& Usui, 1974; Rogers \& Yanagimachi, 1976; Reyes, Goicoechea \& Rosado, 1978). The concentration of calcium in the tubal fluids of the rabbit (Holmdahl \& Mastroianni, 1965) and rhesus monkey (Mastroianni, Urzua \& Stambaugh, 1973) increases following ovulation and the presence of calcium, together with a divalent ionophore, A23187, accelerates the capacitation of rabbit spermatozoa in vitro (Reyes et al., 1978). The removal of the decapacitation factor and the post-ovulatory influx of $\mathrm{Ca}^{2+}$ ions are both specific events which might serve as foci for the regulation of fertility.

The maintenance of sperm viability in the oviducts may also depend upon factors present in the tubal secretions, e.g. glucose (Bishop, 1969), lactate, pyruvate (Iritani, Gomes \& VanDemark, 1969a, b; Carlson, Black \& Howe, 1970; Stone \& Hamner, 1975), amylase (Hochberg, 1974), lactic acid dehydrogenase (Gibson \& Masters, 1970; Lippes \& Enders, 1972), glycerophosphoryl choline diesterase (Iritani et al., 1969a) and an unidentified nondialysable, heat-labile factor found in the genital tract of the ewe and rabbit (Iritani et al., 1969b). The first stage of fertilization, the binding of spermatozoa to receptors in the zona pellucida, appears to be independent of any tubal factor because it will take place in a defined medium such as M199 supplemented with bovine serum albumin (Gwatkin, 1977; R. J. Aitken \& D. W. Richardson, unpublished observations). However, the subsequent penetration of the zona pellucida by the spermatozoa does appear to be influenced by the oviductal secretions. Sperm penetration is preceded by the acrosome reaction which exposes a trypsin-like enzyme (acrosin), on the inner acrosomal membrane (Stambaugh \& Buckley, 1968, 1969; Polakoski, Zaneveld \& Wiłliams, 1972; Zaneveld, Polakoski \& Williams, 1972; Yanagimachi \& Teichman, 1972) and this enzyme is thought to be responsible for digesting a path through the zona pellucida in advance of the penetrating spermatozoon. The importance of acrosin in the penetration process is indicated by the fact that fertilization in vitro (Stambaugh, Brackett \& Mastroianni, 1969) and in vivo (Zaneveld, Robertson, Kessler \& Williams, 1971) can be blocked by the presence of exogenous trypsin inhibitors. Endogenous protease inhibitors have been detected in the tubal secretions of women (Moghissi, 1970; Hirschhauser, Kionke \& Daume,

\section{EXPLANATION OF PLATE 1}

Fig. 1. Disc gel electrophoresis on columns of $7 \%$ acrylamide, $\mathrm{pH} 8 \cdot 9$, of uterine flushings (UF) collected during the early secretory stage of the human cycle and the paired plasma sample. Non-serum proteins are indicated by arrows. Note the particularly dense band with $R a$ value of 0.41. (From Maathuis \& Aitken, 1978a.)

Fig. 2. Murine oocyte containing 11 pronuclei derived from human spermatozoa capacitated in a defined medium (M199: Flow Laboratories) supplemented with $3 \mathrm{mg}$ human serum albumin $/ \mathrm{ml}$.

Fig. 3. Polyacrylamide gel electrophoresis of mouse uterine flushings during Days 4-10 of pseudopregnancy. $\mathrm{A}=$ albumin, $\mathrm{T}=$ transferrin. Note the prominent high molecular weight proteins (arrowed) which appear in the uterine fluids on Days 8-10, as the mice are returning to oestrus. 
PLATE 1

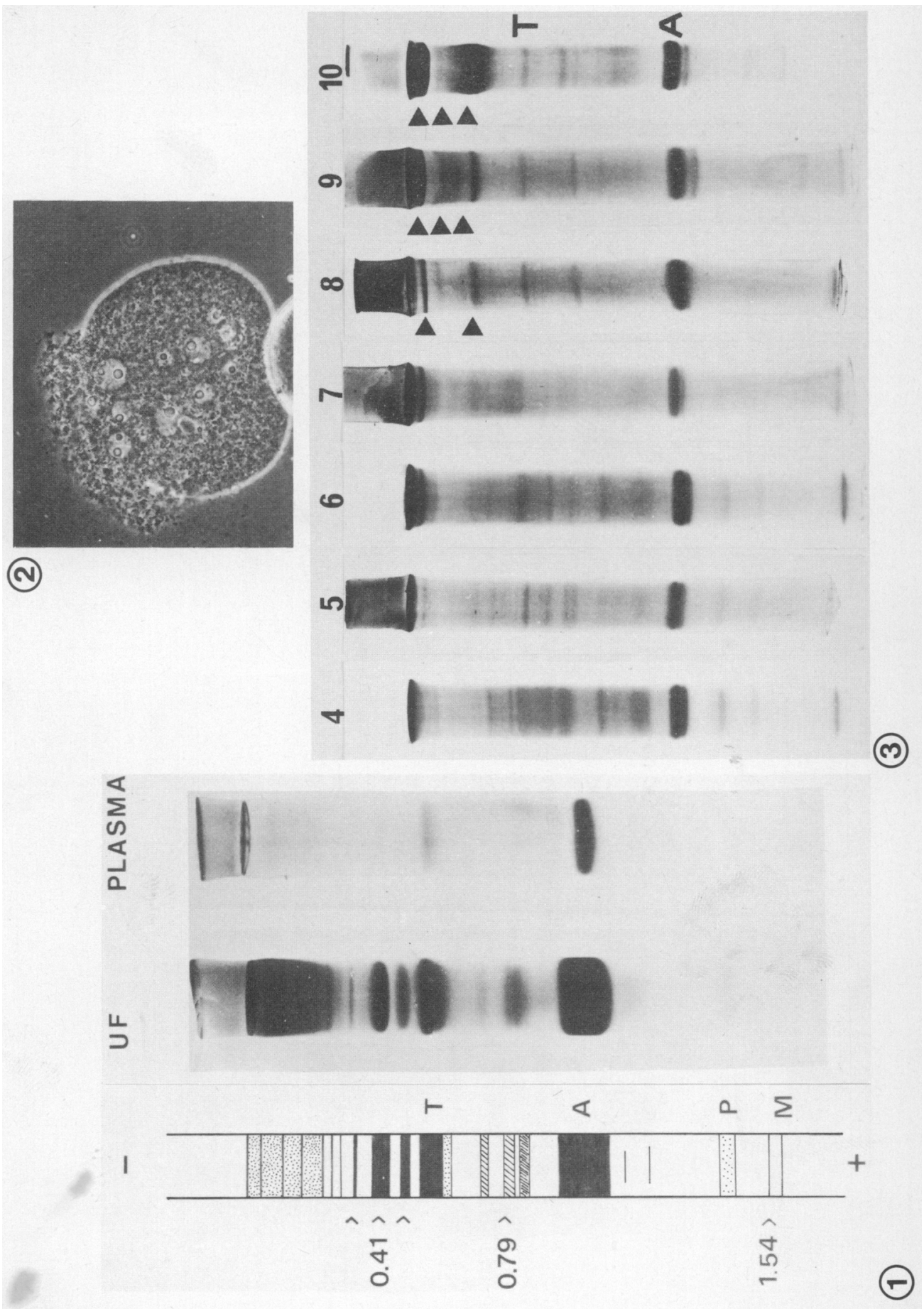


1971), rhesus monkeys (Stambaugh, Seitz \& Mastroianni, 1974) and rabbits (McLaughlin, 1974). In the rhesus monkey a total of 6 protease inhibitors were identified in the oviductal fluids and 5 of them inhibited rhesus monkey acrosin. Two of these inhibitors were derived from serum ( $\alpha 2$-macroglobulin and $\alpha 1$-antitrypsin) while the remainder were thought to be of tubal origin. The major protease inhibitors present in the tubal secretions of the rabbit (McLaughlin, 1974) and women (Moghissi, 1970) appear to be of serum origin. The purpose of these inhibitors is presumably to inhibit fertilization at all stages of the cycle apart from the immediate postovulatory phase during which their concentration declines significantly (Stambaugh et al., 1974; McLaughlin, 1974). In this way the risk of fertilization involving ageing ova, with the attendant hazards of genetically abnormal offspring, is kept to a minimum. In this respect it is of interest that there exists in the human population a genetic variant, designated P1Z (Kueppers, 1973; Cooper, 1978), which is associated with a deficiency in the serum levels of $\alpha$-antitrypsin, the major protease inhibitor in human tubal fluids. Carriers of the P1Z variant suffer from diseases of the lung and liver and, more importantly in the present context, give birth to a high percentage of chromosomally abnormal offspring (Fineman, Kidd, Johnson \& Breg, 1976). It might also be predicted that low levels of $\alpha 1$-antitrypsin in the tubal fluids would be associated with an increase in fertilization rate. If this were shown to be the case, it would explain how such a deleterious genetic variant has become established in the population (Kueppers, 1972).

Another event associated with fertilization which appears to involve the participation of the tubal secretions concerns the loss of the corona radiata from around the oocyte (Mastroianni \& Ehteshamzadeh, 1964). The tubal factor responsible for dispersing the corona cells of the rabbit was shown to be dialysable and heat-stable and was subsequently identified as bicarbonate ion (Zamboni, Hongsanand \& Mastroianni, 1965; Stambaugh, Noriega \& Mastroianni 1969). The bicarbonate ion content of rhesus monkey tubal fluids has been shown to increase following ovulation (Maas, Storey \& Mastroianni, 1977) and it is possible that this change is instrumental in stimulating the dispersal of the corona radiata in this species also. The mechanism by which the bicarbonate ion content of the tubal fluids is controlled is not known. Even so, it seems unlikely that the inhibition of corona cell removal would impede the progress of pregnancy.

There is some evidence to suggest that the next stage of embryonic development, cleavage, is associated with a change in the nature of the tubal secretions. In the rabbit, for example, the cleavage of fertilized oocytes appears to depend upon the removal of an oestrogen-induced inhibitor of embryonic development from the ampullary tubal fluids (Kille \& Hamner, 1973; Stone \& Hamner, 1975; Stone, Richardson, Hamner \& Oliphant, 1977). This inhibitor of embryonic development has been indentified in the oviductal fluids of oestrous rabbits and is known to be dialysable. A similar inhibitor appears to be present in the oestrogen-dominated tubal fluids of the mouse (Cline, Randall \& Oliphant, 1977). The precise physiological significance of these inhibitors is not yet clear although it has been suggested that they serve to slow down "some initial events immediately after fertilization, to allow a proper sequence of development" (Cline et al., 1977). Until definitive evidence for the presence of similar factors in primates has been obtained, their contraceptive potential will remain uncertain.

Another possible function of the oviductal secretions concerns the immunological protection of the zygote from the ravages of the maternal immune system. Using the rosette inhibition test as a criterion for immunosuppressant activity, Morton, Hegh \& Clunie (1974) claim to have demonstrated the appearance of an immunosuppressant factor in the blood serum of mice within $6 \mathrm{~h}$ of copulation. Since it is improbable that significant quantities of this factor could be produced by the eggs themselves it is possible that the immunosuppressive substance(s) is synthesized by the oviduct in response to a stimulus delivered by the pronuclear-stage oocytes.

There is, therefore, some evidence to suggest that the tubal secretions play a part in the control of fertilization and embryonic development. We must now ask whether the synthesis or release of any of these components can be modulated by embryonic or pharmacological means. An influence of the developing embryo on the metabolic activity of the oviduct has been demon- 
strated in the rabbit for such features as D,L- $\left[1-{ }^{14} \mathrm{C}\right]$ valine incorporation (Roy, Gupta, Roy, Karkun \& Kar, 1972) and the ampullary concentration of lactic acid and acid phosphatase (Gupta, Karkun \& Kar, 1970). Similarly the presence of an embryo has been found to influence $\left[{ }^{3} \mathrm{H}\right]$ thymidine incorporation by the mouse oviduct (Freese, Orman \& Paulos, 1973). From a contraceptive point of view elucidation of the nature and extent of these interactions between the embryo and oviduct would seem to be a profitable avenue for research. With respect to the pharmacological control of oviductal secretory activity oestrogen appears to be responsible for such changes as the disappearance of protease-inhibitor activity (McLaughlin, 1974), the presence of inhibitors of embryonic growth (Cline et al., 1977; Stone \& Hamner, 1977) and the appearance of such essential components as calcium, glucose, lactate and pyruvate (Holmdahl \& Mastroianni, 1965). It is, however, difficult to envisage any regimen by which hormones (or anti-hormones) could be administered to interfere with normal tubal function without disrupting ovulation.

\section{The uterus}

\section{Oestrous uterine secretions}

In all species so far investigated, including man, ovulation is associated with the production of a voluminous, protein-rich uterine secretion of low viscosity (Lutwak-Mann, Boursnell \& Bennett, 1960; Fahning, 1965; Aitken, 1970, 1977a; Clemetson, Kim, DeJesus, Mallikarjuneswara \& Wilds, 1973; Meglioli, Kalvoda \& Desaulles, 1973). The physical function of these uterine fluids is to dilate the uterine lumen and thereby create a passage through which the spermatozoa can progress towards the utero-tubal junction. While they are suspended in this fluid the spermatozoa undergo the initial stages of capacitation (Yanagimachi \& Usui, 1974). Although the initiation of capacitation does not seem to be a very exacting function for these fluids, they have a surprisingly complex composition incorporating a large number of non-serum, possibly unique, proteins (Aitken, 1977b, c; Surani, 1977; Pl. 1, Fig. 3). It would be fascinating, and perhaps of practical importance, to know the precise functions of these components.

\section{Progestational uterine secretions}

During early pregnancy the uterus produces a second type of secretion which serves to induce and maintain blastocyst activity over the implantation period. The role of these secretions in the stimulation of embryonic growth became evident as a result of studies on species exhibiting the facultative and obligate forms of delayed implantation such as the roe deer (Aitken, 1974a, b, c), wallaby (Renfree, 1973), fur seal (Daniel, 1971), mouse (Aitken, 1977b, c) and rat (Surani, 1975). In all these species the reactivation of the blastocysts at the end of diapause is temporally associated with an increase in uterine secretory activity. Subsequent research has concentrated on determining the secretory factors responsible for stimulating the blastocysts. The first species to be studied in depth was the rabbit in which implantation was found to be associated with the appearance in the uterine fluids of a major protein termed uteroglobin (Beier, 1968) or, in view of its predicted embryotrophic properties, blastokinin (Krishnan \& Daniel, 1967; Daniel, 1968). A search for similar proteins in other species then followed which, with the possible exception of the fur seal (Daniel, 1972a) and man (Daniel, 1973), was unsuccessful. It is now apparent that in most species the progestational uterine secretions consist of a complex mixture of proteins (Surani, 1977; Aitken, 1977b, c; Pratt, 1977), many of which are thought to have a transport function. Uteroglobin, for example, is now thought to be a progesterone-binding protein (Beato, 1977). In the mouse (Aitken, 1977a), wallaby (Renfree, 1973), rabbit (Daniel, 1972b) and pig (Wyatt, Heap \& Perry, 1976), the evidence suggests that the implanting or elongating blastocyst may have a local stimulatory effect upon the secretory activity of the endometrium. Such an interaction may be particularly important in women in 
whom the quantity of protein released into the uterine lumen during the luteal phase of the nonpregnant cycle is minimal (Maathuis \& Aitken, 1978a). It is therefore possible that the development of full secretory activity in the human uterus requires the presence of a blastocyst. With this possibility in mind we might reflect upon the importance of elucidating the nature of the interactions between blastocyst and endometrium in appropriate animal models.

Hormonally, the control of uterine secretory activity in species not exhibiting delayed implantation, such as the rabbit (Arthur \& Daniel, 1972) or pig (Knight, Bazer \& Wallace, 1973), is thought to be mediated by progesterone. For implantation to take place it is important that these progesterone-dependent secretions are released into the uterine lumen shortly after blastocyst formation. If exogenous steroids are used to delay (Beier, Kühnel \& Petry, 1971; Adams, 1973, 1976) or accelerate (McCarthy, Foote \& Maurer, 1977) release of these secretions in a species such as the rabbit, implantation is prevented. Whether a similar approach could be used to inhibit implantation in women is still open to question. However, the absence of a discrete secretory peak in the mid-luteal phase of the human (Maathuis \& Aitken, 1978a, b) and baboon (Peplow, Breed, Jones \& Eckstein, 1973) cycle is discouraging.

A major secretory product of the luteal-phase human endometrium is prostaglandin (PG) F$2 \alpha$ (Pickles, Hall, Best \& Smith, 1965; Downie, Poyser \& Wunderlich, 1974; Singh, Baccarini \& Zuspan, 1975; Jordon \& Pokoly, 1977; Maathuis \& Kelly, 1978). This compound does not appear to be involved in the control of luteal function in women (Beling, Marcus, Markham, 1970; LeMaire \& Shapiro, 1973; Aitken \& Harper, 1977) as it is in many other species (Aitken \& Harper, 1977) but may be instrumental in initiating the events leading to menstruation. In contrast to the non-pregnant cycle, the endometrial concentration of PGF-2 $\alpha$ is uniformly low during early pregnancy in man (Maathuis \& Kelly, 1978). This observation may be explained in one of two ways: either the decidualized endometrium is incapable of PGF-2 $\alpha$ synthesis or the implanting conceptus produces a factor(s) which suppresses local PGF- $2 \alpha$ anabolism. The latter possibility is the more likely because one of the patients examined by Maathuis \& Kelly (1978) was only 17 days pregnant and despite a normal late luteal-phase endometrial biopsy the PGF$2 \alpha$ levels in the tissue sample were minimal. Isolation of the embryonic factors responsible for the suppression of endometrial PGF-2 $\alpha$ synthesis in women would seem to be a particularly promising area for research which might lead to the identification of an ideal target for contraceptive intervention.

\section{Conclusion}

The tubal and uterine secretions appear to offer several potential opportunities for contraceptive attack. The realization of this potential will, however, depend upon a shift of research emphasis away from the secretions per se and towards their interactions with the embryo.

\section{References}

Adams, C.E. (1973) Asynchronous egg transfer in the rabbit. J. Reprod. Fert. 35, 613-614.

Adams, C.E. (1976) Egg survival relative to maternal endocrine status. In Ovum Transport and Fertility Regulation, pp. 466-472. Eds M. J. K. Harper, C. J. Pauerstein, C. E. Adams, E. M. Coutinho, H. B. Croxatto \& D. M. Paton. Scriptor, Copenhagen.

Aitken, R.J. (1970) Changes in the uterus that precede implantation. M.Sc. thesis, University of Wales.

Aitken, R.J. (1974a) Delayed implantation in roe deer (Capreolus capreolus). J. Reprod. Fert. 39, 225-233.
Aitken, R.J. (1974b) Delayed implantation in the roe deer (Capreolus capreolus). Ph.D. thesis, University of Cambridge.

Aitken, R.J. (1974c) Calcium and zinc in the endometrium and uterine flushings of the roe deer (Capreolus capreolus) during delayed implantation. J. Reprod. Fert. 40, 333-340.

Aitken, R.J. (1977a) Embryonic diapause. In Development in Mammals, Vol. 1, pp. 307-360. Ed. M. H. Johnson. North Holland, Amsterdam. 
Aitken, R.J. (1977b) Changes in the protein content of mouse uterine flushings during normal pregnancy and delayed implantation, and after ovariectomy and oestradiol administration. J. Reprod. Fert. 50. 29-36.

Aitken, R.J. (1977c) The protein content of mouse uterine flushings during pseudopregnancy. $J$. Reprod. Fert. 50, 191-192.

Aitken, R.J. \& Harper, M.J.K. (1977) New methods for the regulation of implantation. Contraception 16, $227-241$

Arthur, A.T. \& Daniel, J.C., Jr (1972) Progesterone regulation of blastokinin production and maintenance of rabbit blastocysts transferred into uteri of castrate recipients. Fert. Steril. 23, 115-122.

Beato, M. (1977) Hormonal control of uteroglobulin biosynthesis. In Development in Mammals, Vol. 1, pp. 361-384. Ed. M. H. Johnson. North Holland, Amsterdam.

Beier, H.M. (1968) Uteroglobin: a hormone sensitive endometrial protein involved in blastocyst development. Biochem. biophys. Acta 160, 289-291.

Beier, H.M., Kühnel, W. \& Petry, G. (1971) Uterine secretion proteins as extrinsic factors in preimplantation development. Adv. Biosci. 6, 165-189.

Beling, C.G., Marcus, S.L. \& Markham, S.M. (1970) Functional activity of the corpus luteum following hysterectomy. J. clin. Endocr. Metab. 30. 30-39.

Bishop, D.W. (1969) Sperm physiology in relation to the oviduct. In The Mammalian Oviduct, pp. 231-250. Eds E. S. E. Hafez \& R. J. Blandau. University of Chicago Press.

Carlson, D., Black, D.L. \& Howe, G.R. (1970) Oviduct secretion in the cow. J. Reprod. Fert. 22, 549-552.

Chang, M.C. (1957) A detrimental effect of seminal plasma on the fertilizing capacity of sperm. Nature, Lond. 179, 258-259.

Clemetson, C.A.B., Kim, J.K., De Jesus, T.P.S., Mallikarjuneswara, V.R. \& Wilds, J.H. (1973) Human uterine fluid potassium and the menstrual cycle. $J$. Obstet. Gynaec. Br. Commonw. 80, 553-561.

Cline, E.M., Randall, P.A. \& Oliphant, G. (1977) Hormone-mediated oviductal influence on mouse embryo development. Fert. Steril. 28, 766-771.

Cooper, D.W. (1978) Inherited variation in plasma proteins. In Biochemical Genetics of Man Eds D. L. H. Brock \& O. Mao. Academic Press, London.

Daniel, J.C., Jr (1968) Comparison of electrophoretic patterns of uterine fluid from rabbits and mammals having delayed implantation. Comp. Biochem. Physiol. 24, 297-299.

Daniel, J.C., Jr (1971) Growth of the preimplantation embryo of the northern fur seal and its correlation with changes in uterine protein. Devl Biol. 26, 316332.

Daniel, J.C., Jr (1972a) Blastokinin in the northern fur seal. Fert. Steril. 23, 78-80.

Daniel, J.C., Jr (1972b) Local production of protein during implantation in the rabbit. J. Reprod. Fert. 31 , 303-306.

Daniel, J.C., Jr (1973) A blastokinin-like component from the human uterus. Fert. Steril. 24, 326-328.

Downie, J., Poyser, N.L. \& Wunderlich, M. (1974) Levels of prostaglandins in human endometrium during the normal menstrual cycle. J. Physiol, Lond. 236, $465-472$.
Fahning, M.L. (1965) Some chemical analyses of bovine uterine fluid and blood serum. Diss. Abstr. 25, 5355 .

Finemann, R.M., Kidd, K.K., Johnson, A.M. \& Breg, W.R. (1976) Increased frequency of heterozygotes for al-antitrypsin variants in individuals with either sex chromosome mosaicism or trisomy 21. Nature, Lond. 260, 320-321.

Freese, U.E., Orman, S. \& Paulos, G. (1973) An autoradiographic investigation of epithelium-egg interaction in the mouse oviduct. Am.J. Obstet. Gynec. 117, $364-370$.

Gibson, C. \& Masters, C.V. (1970) Oviductal lactate dehydrogenase J. Reprod. Fert. 22, 157-159.

Gupta, D.N., Karkun, J. \& Kar, A.B. (1970) Biochemical changes in different parts of the rabbit Fallopian tube during passage of ova. Am J. Obstet. Gynec. 106, 833-837.

Gwatkin, R.B.L. (1977) Fertilization Mechanisms in Man and Mammals. Plenum Press, New York.

Hanada, A. \& Chang, M.C. (1972) Penetration of zonafree eggs by spermatozoa of different species. Biol. Reprod. 6, 300-309.

Hirschhauser, C., Kionke, V. \& Daume, E. (1971) Trypsin inhibitors in the human female genital tract. Acta endocr., Copenh. 68, 413-416.

Hochberg, C.J. (1974) Tubal amylase. Obstet. Gynec, 43, 129-131.

Holmdahl, T. \& Mastroianni, L., Jr (1965) Continuous collection of rabbit oviduct secretions at low temperature. Fert. Steril. 16, 587-595.

Iritani, A., Gomes, W.R. \& VanDemark, N.L. (1969a) Secretion rates and chemical composition of oviduct and uterine fluids in ewes. Biol. Reprod. 1, 72-76.

Iritani, A., Gomes, W.R. \& VanDemark, N.L. (1969b) The effect of whole, dialyzed and heated female genital tract fluids on respiration of rabbit and ram spermatozoa. Biol. Reprod. 1, 77-82.

Jordan, V.C. \& Pokoly, T.B. (1977) Steroid and prostaglandin relations during the menstrual cycle. Obstet. Gynec. 49, 449-453.

Kille, J.W. \& Hamner, C.E. (1973) The influence of oviductal fluid on the development of one-cell rabbit embryos in vitro. J. Reprod. Fert. 35, 415-423.

Knight, J.W., Bazer, F.W. \& Wallace, H.D. (1973) Hormonal regulation of porcine uterine protein secretion. J. Anim. Sci. 36, 546-553.

Krishnan, R.S.C., Daniel, J.C., Jr (1967) Blastokinin: inducer and regulator of blastocyst development in the rabbit uterus. Science, N.Y. 158, 490-491.

Kueppers, F. (1972) Hypothesis to explain heterozygous advantage in a 1-antitrypsin deficiency. In Pulmonary Emphysema \& Proteolysis, pp, 133-137. Ed. C. Mittman. Academic Press. New York.

Kueppers, F. (1973) $\alpha_{1}$-Antitrypsin Am. J. Hum. Genet. 25, 677-686.

Le Maire, W.J. \& Shapiro, A. (1973) Effect of prostaglandin F2 $\alpha$ infusion on the corpus luteum of the human cycle. Adv. Biosci. 9. 115.

Lippes, J. \& Enders, R.G. (1972) The collection and analysis of human Fallopian tube fluid. Contraception 5. 85-103.

Lutwak-Mann, C., Boursnell, J.C. \& Bennett, J.P. (1960) Blastocyst-uterine relationships: uptake of radioactive ions by the early rabbit embryo and its environment. J. Reprod. Fert. 1, 169-185.

Downloaded from Bioscientifica.com at 04/26/2023 11:06:55AM 
Maas, D.H.A., Storey, B.T. \& Mastroianni, L., Jr (1977) Hydrogen ion and carbon dioxide content of the oviductal fluid of the rhesus monkey (Macaca mulatta). Fert. Steril. 28, 981-985.

Maathuis, J.B. \& Aitken, R.J. (1978a) Cyclic variation in concentrations of protein and hexose in human uterine flushings collected by an improved technique. J. Reprod. Fert. 52, 289-295.

Maathuis, J.B. \& Aitken, R.J. (1978b) Protein patterns of human uterine flushings collected at various stages of the menstrual cycle. J. Reprod. Fert. 53, 343-348.

Maathuis, J.B. \& Kelly, R.W. (1978) Concentrations of prostaglandins $F 2 \alpha$ and E2 in the endometrium throughout the human menstrual cycle, after the administration of clomiphene or an oestrogenprogestogen pill and in early pregnancy. J. Endocr. 77, 361-371.

Mastroianni, L., Jr \& Ehteshamzadeh, J. (1964) Corona cell dispersing properties of rabbit tubal fluid. $J$. Reprod. Fert. 8, 145-147.

Mastroianni, L., Jr, Urzua, M. \& Stambaugh, R. (1973) The internal environmental fluids of the oviduct. In The Regulation of Mammalian Reproduction, pp. 376-384. Eds S. J. Segal, R. Crozier, P. A. Corfman \& P. G. Condliffe. Charles C. Thomas, Springfield, Illinois.

McCarthy, S.M., Foote, R.H. \& Maurer, R.R. (1977) Embryo mortality and altered uterine luminal proteins in progesterone-treated rabbits. Fert. Steril. $\mathbf{2 8}$, 101-107.

McLaughlin, K.C. (1974) Enzyme-inhibitors in the reproduction tract fluids: a study of rabbit oviduct fluid trypsin inhibitors and a demonstration of cat seminal plasma antifertility activity. Dissertation, University of Virginia.

Meglioli, G., Kalvoda, J. \& Desaulles, P.A. (1973) Effect of progestogenic substances on the uterine secretion of spayed rats primed with oestradiol. Horm. Res. 4, 97-106.

Moghissi, K.S. (1970) Human Fallopian tube fluid. 1. Protein composition. Fert. Steril. 21, 821-829.

Morton, H., Hegh, V. \& Clunie, G.J.A. (1974) Immunosuppression detected in pregnant mice by rosette inhibition test. Nature, Lond. 249, 459-460.

Noske, I.G. \& Feigelson, M. (1976) Immunological evidence of uteroglobin (blastokinin) in the male reproductive tract and in nonreproductive ductal tissues and their secretions. Biol. Reprod. 14, 704713.

Peplow, V., Breed, W.G., Jones, C.M.J. \& Eckstein, P. (1973) Studies on uterine flushings in the baboon. 1 . Method of collection, cellular composition, and protein electrophoretic profiles in animals with and without intrauterine contraceptive devices. $\mathrm{Am} . \mathrm{J}$. Obstet. Gynec. 116, 771-779.

Pickles, V.R., Hall, W.J., Best, F.A. \& Smith, G.N. (1965) Prostaglandins in endometrium and menstrual fluid from normal and dysmenorrhoeic subjects. $J$. Obstet. Gynaec. Br. Commonw. 72, 185-192.

Polakoski, K.L., Zaneveld, L.J.D. \& Williams, W.L. (1972) Purification of proteolytic enzyme from rabbit acrosomes. Biol. Reprod. 6, 23-29.

Pratt, H.P.M. (1977) Uterine proteins and the activation of embryos from mice during delayed implantation. J. Reprod. Fert. 50, 1-8.
Renfree, M.B. (1973) Proteins in the uterine secretions of the marsupial Macropus eugenii. Devl Biol. 32, 4149.

Reyes, A., Goicoechea, B. \& Rosado, A. (1978) Calcium ion requirement for rabbit spermatozoal capacitation and enhancement of fertilizing ability by ionophore A23187 and cyclic adenosine 3' : 5'-monophosphate. Fert. Steril. 29, 451-455.

Roberts, G.P., Parker, J.M. \& Henderson, S.R. (1976) Proteins in human uterine fluid. J. Reprod. Fert. 48, 153-157.

Rogers, B.J. \& Yanagimachi, R. (1976) Competitive effect of magnesium on the calcium dependentacrosome reaction in guinea-pig spermatozoa. Biol. Reprod. 15, 614-619.

Roy, S.K., Jr, Gupta, D.N., Roy, S.K., Karkun, J.N. \& Kar, A.B. (1972) Studies in physiology and biochemistry of the Fallopian tube. In vitro uptake of D, L-valine- $1 .{ }^{14} \mathrm{C}$ by different parts of the rabbit Fallopian tube during early pregnancy. Endokrinologie 59, 221-226.

Singh, E.J., Baccarini, I.M. \& Zuspan, F.P. (1975) Levels of prostaglandins $\mathrm{F} 2 \alpha$ and E2 in human endometrium during the menstrual cycle. Am. J. Obstet. Gynec. 121, 1003-1006.

Stambaugh, R. \& Buckley, J. (1968) Zona pellucida dissolution enzymes of the rabbit sperm head. Science, N.Y. 161, 585-586.

Stambaugh, R. \& Buckley, J. (1969) Identification and subcellular localization of the enzymes effecting penetration of the zona pellucida by rabbit spermatozoa. J. Reprod. Fert. 19, 423-432.

Stambaugh, R., Brackett, B.G. \& Mastroianni, L. Jr (1969) Inhibition of in vitro fertilization of rabbit ova by trypsin inhibitors. Biol. Reprod. 1, 223-227.

Stambaugh, R., Noriega, C. \& Mastroianni, L., Jr (1969) Bicarbonate ion; the corona cell dispersing factor of rabbit tubal fluid. J. Reprod. Fert. 18, 51-58.

Stambaugh, R., Seitz, H.M., Jr \& Mastroianni, L., Jr (1974) Acrosomal proteinase inhibitor in rhesus monkey oviduct fluid. Fert. Steril. 25, 352-357.

Stone, S.L. \& Hamner, C.E. (1975) Biochemistry and physiology of oviductal secretions. Gynec. Invest. 6, 234-252.

Stone, S.L., Richardson, L.L., Hamner, C.E. \& Oliphant, G. (1977) Partial characterization of hormonemediated inhibition of embryo development in rabbit oviduct fluid. Biol. Reprod. 16, 647-653.

Surani. M.A.H. (1975) Hormonal regulation of proteins in the uterine secretion of ovariectomized rats and the implications for implantation and embryonic diapause. J. Reprod. Fert. 43, 411-417.

Surani, M.A.H. (1977) Qualitative and quantitative examination of the proteins of rat uterine luminal fluid during pro-oestrus and pregnancy and comparison with those of serum. J. Reprod. Fert. 50, 281-287.

Tung, K.S.K. (1976) Considerations for the assessment of the safety of potential vaccines containing reproductive specific antigens. In Development of Vaccines for Fertility Regulation, pp. 127-142. World Health Organization. Scriptor, Copenhagen.

Wyatt, C., Heap, R.B. \& Perry, J.S. (1976) Protein synthesis in co-cultures of blastocyst and endo- 
metrium explants during blastocyst steroidogenesis in the pig. In Proc. Int. Congr. Endocrinology, Hamburg, Abstr. 226, p. 109. Deutsche Gesellschaft für Endokrinologie.

Yanagimachi, R. (1972) Penetration of guinea-pig spermatozoa into hamster eggs in vitro. J. Reprod. Fert. 28, 477-480.

Yanagimachi, R. \& Teichman, R.J. (1972) Cytochemical demonstration of acrosomal proteinase in mammalian and avian spermatozoa by a silver proteinate method. Biol. Reprod. 6, 87-97.

Yanagimachi, R. \& Usui, N. (1974) Calcium dependence of the acrosome reaction and activation of guinea-pig spermatozoa. Expl Cell Res. 89, 161-174.
Yanagimachi, R., Yanagimachi, H. \& Rogers, B.J. (1976) The use of zona-free animal ova as a test system for the assessment of the fertilizing capacity of human spermatozoa. Biol. Reprod. 15, 471-476.

Zamboni, L., Hongsanand, H. \& Mastroianni, L., Jr (1965) Influence of tubal secretion on rabbit tubal ova. Fert. Steril. 16, 117-184.

Zaneveld, L.J.D., Robertson, R.T., Kessler, M. \& Williams, W.L. (1971) Inhibition of fertilization in vivo by pancreatic and seminal plasma trypsin inhibitors. J. Reprod. Fert. 25, 387-392.

Zaneveld, L.J.D., Polakoski, K.L. \& Williams, W.L. (1972) Properties of a proteolytic enzyme from rabbit sperm acrosomes. Biol. Reprod. 6, 30-39. 